\title{
Proving and Circulating the Theory of Natural Selection
}

Like most of her colleagues, Barber was torn between her religious faith and her scientific rationality. She had grown up in a devout Anglican family, as suggested by the Books of Common Prayer held at the Albany History Museum which belonged to numerous members of her family. The church not only provided a much-needed sense of continuity to a migrant community, but also promised emotional and even physical security. Barber and 600 settler women and children had found shelter in the unfinished St John's Anglican Church in Bathurst during the Sixth Cape-Xhosa War, which erupted on 11 December $1834 .{ }^{1}$ During the Seventh and Eighth Cape-Xhosa Wars, affected women and children spent much of their time in a camp in Bathurst as well as in St George's church in Grahamstown. ${ }^{2}$ Due to the scarce sources concerning her religious practices and their impact on her scientific work, I cannot go into more detail here. In the turbulent 1840s, Barber had taken up botany and its pursuit had soon become her 'sovereign remedy to drive away care'. ${ }^{3}$

Over time, her scientific research gave her the security that others sought in their religious faith and community. However, the pursuit of botany and other scientific disciplines was still commonly regarded as a means of religious expression. ${ }^{4}$ Barber, for example, owned a bound edition with issues of the new popular science journal Recreative Science: A Monthly Record and Remembrance of Intellectual Observation, which had first been published in August 1859. Its first editorial posited that humans were created by God already 'gifted with powers to perceive and appreciate the wonders

(C) The Author(s) 2019

T. Hammel, Shaping Natural History and Settler Society, Cambridge Imperial and Post-Colonial Studies Series, https://doi.org/10.1007/978-3-030-22639-8_5 
of his skill in the creation that exists around and above' them. ${ }^{5}$ Recreative science, in that sense, was 'the cultivation of $[. .$.$] physical and mathemati-$ cal inquiry' for 'amusement as well as instruction'. ${ }^{6}$

In 1858, Charles Darwin was compelled to co-publish his article on natural selection with Alfred Russel Wallace, who had proposed a very similar theory during his stay in the Malay Archipelago. ${ }^{7}$ While many scientists and intellectuals accepted the truth of evolution as a principle in some form or another, natural selection as an explanation for adaptation and speciation was instantly controversial. Darwin defined this as the 'principle, by which each slight variation [of a trait], if useful, is preserved'. ${ }^{8}$ Individuals with useful traits were said to be favoured in the struggle for survival and to produce offspring with similar characteristics. For brevity's sake, Darwin called this principle of preservation 'natural selection'? Ever since she had read Darwin's On the Origin of Species (1859) in 1863, Barber found herself in a state of inner turmoil-torn between praising God's signatures in nature and austerely describing her observations of local flora and fauna. ${ }^{10}$

\section{Barber Becomes a DarWinist}

By the time Darwin's On the Origin of Species was published, Barber had been corresponding with the Irish botanist William Henry Harvey for almost twenty years, during which he had been her main scientific correspondent and had had a deep influence on her and her attitude towards natural selection. Little is known about Harvey whose incoming and outgoing letters were destroyed after his cousin had published a bowdlerised memoir of his life in 1869 presumably to conceal his depression. ${ }^{11}$ Harvey received a copy of On the Origin of Species early in 1860. Before having read the entire book, he held a satirical evening lecture in front of the Dublin University Zoological and Botanical Association on 17 February 1860 which his colleagues found 'rather unworthy of the occasion'. ${ }^{12}$

Once Harvey had read Darwin's work, he started accepting aspects of natural selection. ${ }^{13}$ In October 1860, he sent the pamphlet of his short satire, which had been printed for private circulation, to Darwin, expressing his 'repentance'. ${ }^{14}$ On 3 November, Harvey informed his colleague, the American botanist Asa Gray, that his reviews of Darwin had persuaded him to become 'a Grayite'. For Harvey, Gray had succeeded remarkably well in combining the not mutually incompatible Christian doctrine and evolutionary theory. Harvey also argued that especially the book's later 
chapters on geographical and geological distribution of species had convinced him that Darwinism would likely become fashionable with the next generation of scientists. In the meantime, Harvey declared Darwinism to be merely a plausible foreshadowing of the truth, 'something like what, in higher things, Confucianism is to Christianity'. ${ }^{15}$

Harvey's correspondence with Hooker, Darwin and, above all, Gray convinced him to believe in a process of post-creation change by gradual evolution. ${ }^{16}$ Harvey, the born Quaker, had converted to the Church of Ireland, whose more moderate views on the matter enabled him to change his attitude. In May 1861, he published a review in the Dublin Hospital Gazette, where he used biblical quotations as evidence for the general idea of evolution. ${ }^{17}$ Darwin was amused, as he had never expected 'a helping hand from the Old Testament!'18 By the time Harvey died, in 1866, he had provided Darwin with information on the adaptation of Cape climbing plants to their habitat and had come to accept natural evolution supervised by the Creator. Harvey had also raised Barber's interest in the new theory in which she deeply immersed herself since $1863 .{ }^{19}$

Barber's attitude towards evolution followed a similar trajectory, in which she developed a pragmatic understanding of the place of Christianity in this defining scientific debate of the day. Shortly after Harvey's death from tuberculosis, Barber contacted Joseph Hooker, Darwin's friend and colleague, explaining her approach to botany and the ease with which she accepted the assumptions of both science and religion:

I do not know whether you give preference to curious or beautiful plants for publication, Dr Harvey and myself would mostly "go in" for the marvelous [sic] and the strange, either in appearance or in habits, and our favorite [sic] motto was "Oh Lord how wondrous are thy works \&c." 20

Barber came to combine her natural theology with a strong conviction in natural selection. At the time, she was heavily engaged in her work for Layard on local birds. He was a Darwinist, and her correspondence with him may have further convinced her. At the same time, she believed that God held nature 'in perfect order' and 'in harmony and love', ${ }^{21}$ something which she sought to prove in her local environment. In 1867, she conceded for the first time in a publication that she was 'a believer' in 'the laws of natural selection'.22

In her travel journal (1879), she praised the infinity of wonders to be found in 'the Book of Nature' which could not be grasped by the human 
mind and attributed the existence of species which had successfully adapted to the varying conditions of their habitats to 'the hand of Providence'. ${ }^{23}$ In contrast, she bemoaned the divided churches, the empty church buildings and the loss of Christian values in the colony that rendered its residents unrighteous, greedy for wealth and hungry for power. She thus became reluctant to attend Anglican prayers and services. ${ }^{24}$ In the few instances that she mentioned going to church, she had done so while visiting relatives whom she had accompanied to a service. ${ }^{25}$

Alan Cohen has described Barber as 'almost agnostic', ${ }^{26}$ similar to Darwin who privately pondered the insoluble 'mystery of the beginning of all things' and had to content himself with 'remain[ing] an Agnostic', ${ }^{27}$ a term coined by Thomas Huxley in 1869 to describe an "honest doubter", someone whose private struggle to hope and believe what he could was no longer any threat to society's stability'. ${ }^{28}$

The Victorian 'crisis of faith' had begun as early as the 1830s, when Charles Lyell's geological work proved the vastness of time. ${ }^{29}$ Many churchmen who were collecting natural history specimens in their spare time greeted Darwin's theory with enthusiasm. ${ }^{30}$ One of these was Frederick Temple, who would later become Archbishop of Canterbury. He claimed at a meeting of the British Association for the Advancement of Science on 1 July 1860, for example, that God disseminated his work through the effects of slow natural causes and argued that the 'doctrine of Evolution is in no sense whatever antagonistic to the teachings of Religion'. ${ }^{31}$ At the same time, there were doubters who were concerned with whether the theory could explain the range of characteristics observed among all the living organisms and who did also not believe that evolution could work without the guiding hand of a Creator. Yet, several influential public figures in Britain were also crucial in making room for the acceptance of the theory in the public discourse. Novelist Charles Kingsley, for instance, was convinced that God had programmed natural selection to allow the world to regulate itself. ${ }^{32}$

Darwin himself remained in constant contact with his readers by letter and throughout his lifetime published six editions of $O n$ the Origin of Species, indicating that the acceptance of evolutionary theory was a gradual process. ${ }^{33}$ By the late 1860 s, the theory of evolution by natural selection was widely accepted in the English-speaking world and beyond.

Barber was one of the first naturalists at the Cape to become convinced by the theory of evolution by natural selection, but increasingly found herself in good company. ${ }^{34}$ In 1868, the editor of the Cape Monthly 
Magazine (CMM), Roderick Noble, a professor of physical science and English at the South African College, gave a speech at the South African Library in which he acknowledged the effects of evolution, but underlined that these did not undermine scriptural truths. He believed that evolution served to reinforce humans' view of the omnipotence of God. ${ }^{35}$

Historian of South Africa Saul Dubow and geographer and intellectual historian David N. Livingstone have argued that Darwinian ideas were fiercely debated at the Cape in the late 1860s and 1870s, particularly after the publication of Darwin's The Descent of Man and Selection in Relation to Sex (1871), which applied the theory of evolution by natural selection to human beings. By the early 1870s, Darwin's theories were thus fairly widely discussed among intellectuals in Cape Town. ${ }^{36}$ Outright rejection was relatively rare, as the discussion and some attempts at amelioration of the main thrusts of some of his arguments in the Cape Monthly Magazine $(C M M)$ show. ${ }^{37}$

The $C M M$ was a journal established in 1857 to contribute to the intellectual development of the colony. ${ }^{38}$ From 1856 to 1858 , there was also the Grahamstown-based Eastern Province Monthly Magazine, which existed in friendly rivalry to the $C M M$, mirroring the political tensions between the eastern and western parts of the Colony. Similar to the Whig Edinburgh Review of the early nineteenth century, the CMM sought to foster a moral and commercial community in which the rising middle-class intelligentsia would have a voice. Unlike imported media, the CMM also provided a vent for Cape public opinion. The journal combined the genre of the British scientific quarterly with that of popular magazines by including travel reports, poems and fiction aimed at both informing and entertaining its readers. This made it an important medium for the circulation of ideas and, at a time when authors were still unspecialised in disciplinary terms, this format suited their purposes well. ${ }^{39}$

Evolution was a hotly debated topic in the CMM. There are many ways to illustrate this, but perhaps the strongest index is the publication of extracts from a lecture given by governor Henry Barkly at the South African Library in May 1871. In it, he exempted humans from the evolutionary process due to the absence of transitional forms. Yet, he was convinced that other genera and species were formed through evolution. He thus fused creationist with evolutionary mechanisms and professed to have 'the highest respect' for Darwin. ${ }^{40}$ Barber was very interested in the reception of Darwin's theory and most likely followed the discussion in the CMM. 
She was also interested in how Darwin was received in Europe, as she sought to remain immersed and an active participant in the debate. For example, she asked Hooker whether he could send her a copy of John Tyndall's address to the British Association Assembly at Belfast in 1874. ${ }^{41}$ She was keen on reading it and had had 'no chance of doing so in these outlandish parts'. ${ }^{42}$ In his address, the Anglo-Irish physicist argues that, according to ancient Greek atomism, material atoms could explain the world. He thereby takes a stance in a matter that scientists had hitherto left to theologians. For this theory, he was branded a 'material atheist', which was of great interest to Barber who was sharpening her line of argumentation. ${ }^{43}$

Besides following scientists' debates, her embracing transcendentalism by the late 1870s helped her combine her belief in the 'over-soul' (God) which united all people as one being with evolutionary theory. The philosophical movement originated in the eastern US in the late $1820 \mathrm{~s}$ and 1830s. Its most prominent representative was Ralph Waldo Emerson, the American essayist, lecturer, poet and ex-pastor, who was opposed to the contemporary general state of spirituality and intellectualism. According to this philosophy, nature and humans are inherently good, and the individual is at its best when independent and self-reliant. ${ }^{44}$ Institutions and society, Emerson and Barber believed, corrupted the individual and that true community could only come into existence when real individuals met. Barber believed that every living creature bore the imprint of a higher power and that all objects in nature shared a special connection with each other. All living creatures were responsible for their own happiness, and it was their own fault if they were not happy, 'for the blue sky bends over all' ${ }^{45}$ As she could no longer find comfort in her religious community, she praised nature and was convinced that:

$[\ldots]$ if it were possible in this "work-a-day world" for weak human beings to cast off entirely the worry of their daily lives, and to offer up their souls in true and earnest prayer, it would be here in the forest, in this solitary church, "far from the madding crowd", surrounded by the beauties of nature, the work of God's hands in the temple, of the woods.

"If thou art worn and hard beset

With sorrows that thou woulds't forget,

Go to the woods and hills - no tears

Dim the sweet face that Nature wears." 46 
Literary works heavily influenced Barber's views of nature, as her reference to Thomas Hardy's novel Far from the Madding Crowd (1874), set in the fictional county of Wessex in rural southwest England, indicates. And the last four lines confirm her interest in transcendentalist literature: they are the last stanza of Henry Wadsworth Longfellow's poem Sunrise on the Hills (1825).$^{47}$ In the poem, the narrator visits the hills, describes the landscape and recommends that readers should seek comfort in nature when their lives are burdened, which became one of Barber's guiding principles in life.

Barber found confirmation for her attitude towards religion and nature in religious leaders and conservationists from both the Cape and the US. In her travel account, she mentioned that she and the first Bishop of Natal from the Church of England, John William Colenso, whom she had met in Pietermaritzburg, did not 'belong to the wrangling communities' and preferred worshipping in the forest and praising the Creator's 'marvellous works, where all is peace and harmony'. ${ }^{48}$ John Muir (1838-1914), the Scottish-American naturalist and early advocate of wilderness preservation in the US, like Barber, valued nature as a source of recreation for the human spirit. Barber advocated for botanical gardens in urban spaces and was part of the Kimberley Botanical Gardens' committee in $1877 .{ }^{49}$ She particularly promoted the planting of indigenous trees in botanical gardens, such as in Durban, where she saw trees that were not to be found in other gardens where 'exotics predominate to the exclusion of our own lovely species'. ${ }^{50}$ Similarly, Muir later lobbied for the introduction of national parks, which he in 1912 described as 'Nature's cathedrals, where all may gain inspiration and strength and get nearer to God'. ${ }^{51}$ This statement is very similar to Barber's own views. She employed 'wilderness' as a concept to describe idealised pure nature, a place of natural balance and order, serving as a backdrop for human action. ${ }^{52}$

During the 1870s, Barber developed what was later succinctly described and propagated by South African author Olive Schreiner (1855-1920) as pagan animism, namely the strong belief in the interconnectedness of human, animal, plant and spiritual worlds. ${ }^{53}$ Barber and Schreiner do not seem to have known or corresponded with each other, despite their physical proximity at the Cape and similarity in worldviews. ${ }^{54}$ Yet, Schreiner seems to have further developed Barber's view in many respects, as will be shown in different parts of this chapter. In 1884, Schreiner admired and associated herself with the views of Emerson and declared herself in complete agreement with his philosophy. ${ }^{55}$ Through this approach, she sought 
to undermine hierarchical thinking by advocating for the unification of the natural, spiritual and human realms within a conception of nature as a living being in its own right. ${ }^{56}$ Barber did not just support the theory of evolution by natural selection but actively looked for evidence in her surroundings.

\section{Barber's Corroborative Evidence for Natural SELECTION}

In 1864, Barber became fascinated with the pollination of flowers by insects. ${ }^{57}$ Her research on the topic over the following years resulted in the publication of two of her articles in The Journal of the Linnean Society (Botany) in 1869 and $1871 .{ }^{58}$ Darwin had already supported the publication of her previous article on the fertilisation of another orchid, Liparis bowkeri, which was read to the Linnean Society in London on 6 February 1868..$^{5}$ Barber made an effort to market her knowledge on cases that confirmed natural selection. She wrote to Hooker that she had numerous interesting observations to make which 'point towards Mr Darwin's theory as to the true one (the natural system I might say) ${ }^{\prime} .{ }^{60}$ She offered to provide Darwin and Hooker with much information on the subject 'relative to things of this country', which made her a valuable Cape co-worker.

Darwin also learned about Barber's interesting observations from Trimen. Profoundly influenced by On the Origin of Species, Trimen had once seen Darwin in the Insect Room at the British Museum but had lacked the courage to approach him. ${ }^{61}$ However, when Trimen realised on reading Darwin's On the Various Contrivances by which British and Foreign Orchids Are Fertilised by Insects (1862) that they were both interested in the fertilisation of Cape orchids, he introduced himself towards the end of 1862. ${ }^{62}$ At the time, Trimen was working on what was to become his first scientific article on the functional morphology of the orchid Disa grandiflora (now Disa uniflora). Barber's letters provided Trimen with important information on the subject. Darwin published Trimen's first article in $1863-1864 .{ }^{63}$ From the beginning, Barber was vital for Trimen's career in the making.

In 1863, Trimen informed Darwin of Barber's observations on moths that had destroyed the previous season's peach harvest in Albany, ${ }^{64}$ a problem both men had been pondering. Trimen told Darwin that there was supposedly a moth in Grahamstown, which he identified as Achea Chamaleon Guén, a quadrifid noctua, that could perforate fruit with its 
proboscis ${ }^{65}$ While Trimen himself did not hold moths capable of penetrating such strong membranes, Darwin believed that nocturnal moths pollinated orchids when puncturing their nectaries to obtain nectar but had no evidence in support of this theory. Barber's letters convinced doubtful entomologists that this was indeed possible. Interestingly, Barber provided Darwin with this evidence without having fully read his Fertilisation of Orchids, from which only the extracts which appeared in the Gardeners' Chronicle had been accessible to her. ${ }^{66}$ Barber became progressively more convinced of natural selection.

The advocates of the theory considered mimicry-namely, the similarity of one species' appearance to that of another with the corresponding benefit of protection - to be one of the first important proofs of Darwin's explanation of how some species evolved at a faster pace than others. In 1861, the theory that natural selection altered the appearance of butterfly species to resemble that of other species, even if unrelated, had piqued not only Barber's interest but also that of the wider scientific community. This process, a form of mimicry, by which harmless butterfly species varied their own appearance according to the effects of environmental influences, applying the warning signals of a harmful species when a predator was near, became known as Batesian mimicry, named after the English naturalist Henry Walter Bates and his work on butterflies in the Brazilian rainforests. ${ }^{67}$

The first article which Barber wrote on camouflage was an 1868 paper on the stone grasshopper found in the Grahamstown area. This she sent to Trimen, who criticised her for lumping together different grasshopper species and thus did not support its publication. ${ }^{68}$ However, Hooker read the article to the Linnean Society in London. ${ }^{69}$ One reason for the latter's enthusiasm was that her article had confirmed his example of lizard camouflage from his Himalayan Journals (1854). ${ }^{70}$ Darwin, meanwhile, regretted that Barber had not enclosed pinned specimens of the grasshopper on differently coloured surfaces which would have confirmed her observation. Like Trimen, he was not convinced by Barber's argument and likewise did not support the paper's publication. ${ }^{71}$

Barber used many passages from the Bible which was unusual for scientific publications at the time. She, for instance, described the grasshopper as follows:

the "lines have fallen to him in pleasant places" he is a happy little creature living in ease and plenty, basking the live long day in the sunshine, and 
chirping his merry song, and dun though his coat may be, he can nevertheless boast of rainbow-colored hues, $[\ldots]$ and to the wind he is equally indifferent for like Friar John in Marmion - "But little cares he or kens which way it blows!"72

The first quote is a passage from Psalm 16:6, 'The lines are fallen unto me in pleasant places; yea, I have a goodly heritage. ${ }^{73}$ This illustrates the impact of Anglicanism on her scientific descriptions. The second is from Scottish writer Sir Walter Scott's poem Marmion: A Tale of Flodden Field (1808) and underscores her deep knowledge of literature. ${ }^{74}$

Had Barber attached a watercolour illustrating the grasshopper's camouflage and offered fewer supporting quotations from the Bible and other literary works, she may have considerably strengthened her argument. While quoting from poetry or prose and discussing novels was common in scientific correspondence, ${ }^{75}$ it was unusual in short scientific papers. Yet, she had hitherto enjoyed little exposure to their conventions, as her correspondence was her main source of information. ${ }^{76}$ Barber later sent specimens of the stone grasshopper from the Grahamstown area to John Obadiah Westwood, professor of zoology at Oxford, who had promised to classify these for her and who she hoped would also print her paper. ${ }^{77}$ However, Barber's article remained unpublished. The draft paper and its story of non-publication show how Barber's scholarly possibilities differed from those of her European counterparts and how these disparities are reflected in her writing.

\section{Butterfly Mimicry and the Birth of a New Research FIELD}

Butterfly mimicry occupied the thoughts of entomologists such as Barber and Trimen. The latter could not travel between 1862 and 1866 as the cataloguing of butterflies in the South African Museum occupied all his time, which made Barber's fieldwork and correspondence on the subject all the more important to him. Their correspondence between May 1863 and December 1866 primarily focussed on individual species of moths and butterflies that Barber observed, collected, prepared in her garden or while travelling and sent to Trimen. ${ }^{78}$

In 1866, they came across a curious case that would occupy them in the years to come. After capturing his first Papilio cenea soon after his arrival at the Cape in 1858, Trimen had long pondered over its relationship to 
Papilio merope. Since 1864, Barber had also been puzzled by the absence of merope females and male ceneas. ${ }^{79}$ By 1866, she questioned whether male cenea existed at all and, after checking all available collections at the Cape, Trimen shared her doubts. ${ }^{80}$ After reading Bates's article on the Amazonian Heliconidae, ${ }^{81}$ he began to research the problem intensively. He soon suspected that species previously regarded as separate, such as Papilio cenea, Papilio dionysos, Papilio hippocoon and Papilio trophonius, were four forms of the female of one species. He seems to have been unaware of Alfred Russel Wallace's 1865 article on 120 species of Papilionidae butterflies from the Malay Archipelago on the basis of which Wallace had argued that only the females were mimetic. ${ }^{82}$ Barber remained confused about why she was still unable to find a female merope in $1866,{ }^{83}$ while Trimen failed to find either female Papilio merope or male Papilio cenea in Natal in 1867 or in British collections and thus became more and more convinced of his own theory. ${ }^{84}$ In December 1867, he informed the Entomological Society in London of his ideas and promised that he would provide more evidence at a later stage.

Their research was soon communicated to their colleagues through Trimen's publications. On 5 March 1868, Trimen presented his paper 'On some Remarkable Mimetic Analogies among African Butterflies' to the Linnean Society in London and saw its publication in the society's transactions in 1869. ${ }^{85}$ In this article, Trimen showed how Papilio cenea imitated Danais echeria, Papilio hippocoon and Papilio dionysos Danais niavius ${ }^{86}$; how Papilio trophonius copied Danais chrysippus; and that the four Papilionidae previously regarded as separate species were all female forms of Papilio merope.

Trimen's paper was not well-received by entomologists such as William Chapman Hewitson (1806-1878), who had one of the largest contemporary collections of butterflies in England, and John Obadiah Westwood, who was familiar with Wallace's earlier report on different female forms of the Indian butterfly Papilio pammon. ${ }^{87}$ Hewitson agreed that hippocoon and dionysos were one species, but would not accept that they might both be females of merope. In Madagascar, he had seen females that resembled the male merope and commented that he was incapable of imagining that mainland males of the same species indulged in a 'harem of females' all differing as widely in appearance from each other as from other species in the genus. While he claimed to know of examples that had recently become known, he did not believe in differences between the sexes of one species that were as significant as between species in the genus. ${ }^{88}$ Equally shocking 
was the power of females to dramatically change their appearance. In Trimen's obituary in 1916, the paper was described 'a classic' which had initially been 'received with little less than scorn by the then opponents of the Darwinian theory, and certainly with more opposition than were those by Bates and by Wallace, [...]. We in these days cannot understand the dislike and even bitterness of that controversy [... ${ }^{\text {' }}{ }^{89}$

In June 1868, Barber suggested to Trimen that the only definitive proof with which they could provide their critics would come through the raising of adult butterflies from Papilio cenea eggs..$^{90}$ She or Trimen may, by now, have read Wallace's aforementioned article in which he had focussed on how butterfly eggs turned into butterflies with different appearances. In any case, Trimen asked her to do so, a task to which Barber agreed if she could find any. ${ }^{91}$ She was unsuccessful in this regard in the years 1869 and $1870,{ }^{92}$ but continued to describe merope and emphasise that natural selection allowed it to blend into its surroundings, thus providing it with an extra means of protection.

With Barber's observations at hand, ${ }^{93}$ Trimen addressed other entomologists such as the Eastern Cape-based farmer and naturalist James Philip Mansel Weale (1838-after 1911). Weale was an old school friend of the Trimen brothers. He studied law at Oxford, then took up farming in South Africa from the mid-1860s until about 1890, when he returned to England. His special interest was the pollination of flowers by insects. He corresponded with Darwin, who presented several papers to the Linnean Society for him. Weale distributed questionnaires in the Cape Colony for Darwin's research on The Expression of the Emotions in Man and Animals in $1871 .{ }^{94}$ He reported having six cenea-merope larvae in 1873; from the first four of these pupae, two specimens of merope, a hippocoon and a cenea, emerged. Two were sent to Trimen, one of which died and out of the other emerged a merope. A later brood resulted in a trophonius. ${ }^{95}$ Trimen and Weale thus observed four forms of the female from a single species, and Trimen introduced Barber to his theory that cenea, merope, dionysos, hippocoon and trophonius were not distinct species of Papilio, but a few of over thirty different forms of the African mocker swallowtail now known as Papilio dardanus. She immediately agreed with Trimen, who in 1874 published his own paper on 'Observations on the Case of Papilio merope, with an Account of the various known Forms of that Butterfly' in the Transactions of the Entomological Society, in which he described the female cenea as a hybrid between Merope and Danais (Amauris) Echeria. ${ }^{96}$ 
In 1881, Barber's brother James Henry Bowker also observed the mating of a Papilio merope and a Papilio cenea and therewith verified one of the most fascinating cases of Batesian mimicry. ${ }^{97}$ These, it was confirmed, were two of the over thirty different forms of the African mocker swallowtail now known as Papilio dardanus.

Barber continued to observe equivalent cases in other animals. In 1872, she reported witnessing that the Klep salamander in Kimberley, like the chameleon and the stone grasshopper of Grahamstown, 'possessed the power of altering its colours' and even doing so 'far more rapidly than the chameleon'. Before experimenting by putting these animals in several different places, she had believed that 'colours were stationary'. ${ }^{98}$

Trimen had seemingly been unaware of her experiments with rearing Papilio nireus. Barber had asked her brother James Henry to inform him during a visit to Cape Town, but he forgot. ${ }^{99}$ In June 1874, she sent her paper to Hooker ${ }^{100}$ who enthusiastically forwarded it to Darwin a month later, summarising Barber's 'clever suggestions'. This indicates that Barber aimed for British approval and first addressed scientists in the metropole, which changed with the foundation of the South African Philosophical Society, the equivalent to the Royal Society of London, in 1878.

Hooker listed a number of examples of similar cases he had witnessed but had never been quite convinced until reading Barber's paper. ${ }^{101}$ In her paper, Barber had reported on her experiments with larvae and pupae that adapted their colour depending on their surroundings. For instance, they turned into dark green matching the colour of the orange tree, pale yellow green like the bottle-brush, yellow like the wooden frame of the cases in which they were reared and on which she placed them. ${ }^{102}$ In nature, the pupa thus resembled the colour of the leaves of the plants it fed upon, thereby ensuring its protection. She aimed to prove these observations with her drawings. She had learned from the rejection of her grasshopper paper (1868) and took Darwin's advice of including a coloured illustration into account. ${ }^{103}$ The result was her most well-known article 'Notes on the Peculiar Habit and Changes which Take Place in the Larva and Pupa of Papilio nireus' published in the Transactions of the Royal Entomological Society of London in 1874. ${ }^{104}$

While Darwin did not find the publication of a coloured plate of the fertilisation of Duvernoia adhatodoides necessary, ${ }^{105}$ he supported the publication of this plate to convince the article's readers of this case of mimicry. As Darwin no longer travelled abroad, he required corroborative evidence from all over the world to convince as many people as possible of 
his theory of evolution by natural selection and thus found Barber's paper 'very curious'. He soon agreed that it should be published and asked Hooker to visit him so that they could discuss to which publication it should be sent. ${ }^{106}$ Entomologist and evolutionary biologist Henry Walter Bates also supported the paper's publication due to the 'more striking than usual facts' which it contained. ${ }^{107}$ The article was then presented to the Entomological Society of London and immediately published in its Transactions. ${ }^{108}$ In March 1875, Darwin also sent the paper via government dispatch to the governor of the Cape Colony, Sir Henry Barkly, who he thought would also be interested. ${ }^{109}$

For Darwin, Barber's paper was thus of great importance and fully worthy of his endorsement. Barber's mimicry research on butterflies added to Darwin's evidence on the topic from the Americas and Asia. In South Africa, her observations and analysis were crucial in initiating and establishing mimicry research as a field of its own. It has been argued that Trimen was the first to regard mimicry as a field of research in its own right. Trimen's address on 'Mimicry' in 1898 was his most valuable contribution on the subject, and greatly enhanced by his own observations from his long period of residence in South Africa. ${ }^{110}$ Barber was aware of Darwin's dependence on informants such as herself. Indeed, she wrote to Hooker with the message that Darwin should 'command' her observations from the Cape if they were of use to him. ${ }^{111}$ By thus urging a response from Darwin, Barber attempted to make use of his dependence for her own scientific and career purposes.

\section{Sexual Selection and Women's Position in Society}

As a mechanism of natural selection, Darwin's theory of sexual selection attracted much attention. Unpublished sketches show that Darwin had been pondering this notion since at least $1842 .{ }^{112} \mathrm{He}$ alluded to it in Origin of Species, where he devoted two pages to his claim that sexual selection accounted for inter-gender differences in colour, pattern or structure in species in which males and females otherwise exhibited the same habits. Darwin argued that sexual selection 'depends, not on a struggle for existence, but on a struggle between the males for possession of the females; the result is not death to the unsuccessful competitor, but few or no offspring. Sexual selection is, therefore, less rigorous than natural selection'. ${ }^{113} \mathrm{He}$ also noted that female birds, for example, appeared to select what they regarded as the most beautiful or melodious mates. ${ }^{114}$ In 
the 1860s, Darwin continued to puzzle over the persistence of maladaptive traits such as the bright plumage and long tail of the peacock, which, by providing no survival advantage, could not be explained by natural selection alone.

At the same time, a number of novels were published that debated sexual selection, as well as rituals of mating and courtship among humans, thereby seeking to combine the traditional courtship plot, at the time in a state of flux, with an interpretation of meeting and mating that became increasingly based on biological models. ${ }^{115}$ Literary scholars have shown that these novels, mostly by women authors, influenced Darwin and the way in which he developed and shaped his theories of sexual selection. ${ }^{116}$ In The Descent of Man, and Selection in Relation to Sex (1871), Darwin argued that sexual selection depended on the advantage of individuals over others of the same sex to attract the other for reproduction. ${ }^{117}$ There were thus two basic types of sexual selection: intrasexual selection or maleon-male competition for mates which could result in the death or ostracising of defeated rivals while females looked on passively; and intersexual selection, otherwise typically known as female choice, in which males (in most cases) attempted to charm the opposite sex (usually females). Here, females were no longer passive, but actively selected the partners of their preference. ${ }^{118}$

The largest focus of his explanation of sexual selection in The Descent was on birds, even though, according to current ornithologists, Darwin was 'not much of an ornithologist'. ${ }^{19}$ Darwin's discussion of birds in The Descent focused on other people's observations, primarily on birds in North America and Australia. Only 68 pages of The Descent were on humans, while 200 were on birds. ${ }^{120}$ Moreover, almost a third of the seventy-four wood engravings in the first edition were of birds, far exceeding any other subject of illustrations in the book. ${ }^{121}$ Darwin explained this emphasis with the argument that birds were the most aesthetic animals after humans and possessed secondary sexual characteristics which were more varied and conspicuous than in any other class of animals. ${ }^{122}$ Barber explained human interest in birds in the following way: 'For we all like the birds, they awake us with their sweet voices in the early morning and in the "gloaming" their songs are still with us. ${ }^{123}$ Birds have also been described as 'large, sexually reproducing, diploid, warm-blooded vertebrate animals, with separate sexes, color vision, parental care, internal fertilization, and relatively large brains. These traits make them more like us than the majority of other living things'. ${ }^{124}$ These aspects might also have influenced his 
choice of birds. For Darwin, when humans observed male birds displaying their colourful plumage to females, they would thus recognise and find it 'impossible to doubt that the females admire the beauty of their male partners', ${ }^{125}$ the very point which he sought to emphasise in his theory.

At the Cape, both natural and sexual selection were also often discussed through the prism of birds. Ornithologist, geologist, scientific traveller and medical practitioner Hugh Exton, for instance, adopted the theory of natural selection in 1871 during his research on whether the nest-building capabilities of birds were a natural instinct or an acquired adaptive trait. ${ }^{126}$ A few years later, he favourably reviewed Layard's Birds of South Africa which had followed Wallace's system of classification developed in Contributions to the Theory of Natural Selection. This system took each species' order and its modification according to changes in its surroundings into account. ${ }^{127}$ Among other references to Darwin, Hexton argued for the adaptive role of mimicry in the colouration of cuckoo eggs.

British and Cape intellectuals generally accepted The Descent more favourably than Origin of Species. Shortly after the former's publication, Hooker informed Darwin that while dining out three days in a week he noticed that the idea of evolution was accepted and that The Descent was calmly discussed wherever he went. ${ }^{128}$ An anonymous review in the CMM in 1871, for example, reflected on the role sexual selection played in racial differentiation. The reviewer argued that the application of Darwinism to the moral and intellectual spheres was paramount and quoted Catholic theologian Cardinal John Henry Newman who insisted that The Descent was 'pregnant with warning to those who would hastily condemn views of the mental and moral status of animals such as Mr Darwin so ably suggests'. Newman had become known nationally by the mid-1830s and is remembered as an influential figure in English religious history in the nineteenth century. Despite Newham often being seen as a strict opponent of evolution, he considered it to be compatible with Christianity. ${ }^{129}$ $\mathrm{S} /$ he concluded that The Descent would meet with severe and hostile criticism due to its speculative nature, but should not be ignored as it was the foundation theory from which the development of organic life could be explained. ${ }^{130}$ This review encapsulates the contemporary debate at the Cape, to which Barber, as a frequent contributor to the $C M M$, added.

While the theory of sexual selection initially seemed an unlikely assertion to Barber, she started providing relevant cases to naturalists in the mid-1860s. Her observations of birds she sent to Layard. As their correspondence did not survive and her quotations in Birds of South Africa 
(1867) are mostly undated, it is impossible to know when exactly she wrote these statements to him. Barber argued:

I have never seen a wild one [guinea fowl] with white feathers in its wings. It is contrary to the laws of natural selection $[\ldots]$ for nature to produce any form that is useless or hurtful to her, such as white wing-feathers would be to wild guinea-fowls, for they would at once point out to wild-cats, owls, hawks, and sports-men, the direction in which the bird had flown or ran (for in crossing all rough places they open their wings while running); and I am inclined to think that if they do occur in any part of the colony with white wings, it is when they have accidentally been crossed with the tame, whitebreasted guinea-fowl that is so common (especially amongst the Dutch colonists) nearly all over the colony. ${ }^{131}$

Barber thus initially provided an alternative explanation: she did not explain the occurrence of the white wing-feathers in guinea fowls with reference to sexual selection, but posited a hybridisation between wild and domesticated birds. She was, however, certainly aware of theories of sexual selection at the time, whether through reading the above-mentioned novels, from the public debate or from her own reading of Darwin's and Spencer's works. In another letter, presumably written after discussing the guinea fowl, Barber, now convinced in Darwin's explanation of sexual selection, informed Layard that she had observed a relevant case of female selection when the male Cape rock-thrush sung his rather lively song from a conspicuous position from where he could be heard and seen best and could thus quickly be chosen by a female. ${ }^{132}$ These two examples illustrate how Barber, initially sceptical of sexual selection, came to adopt the concept and found evidence for it in her immediate environment. She then promised Trimen in 1868 that she would report on any examples of sexual selection which she may come across. ${ }^{133}$

The Descent was deemed 'a literary sensation', 'must-read' and 'as exciting as any novel'. ${ }^{134}$ It was therefore widely read and discussed. Darwin was aware of his theory's social implications and deliberately included (at times multivalent) passages for his conservative, misogynist and feminist readers. I thereby argue that his readers were not just (deliberately or not) misreading him, but that in his very project Darwin set up arguments for both opinion leaders.

A number of scholars have described Darwinian evolutionary science as 'intrinsically anti-feminist'. ${ }^{135}$ In his remaining texts, numerous passages can be found that suggest this view. In his correspondence, for instance, 
there is a striking letter that he wrote in reply to Caroline Augusta Kennard (1827-1907), an American campaigner for women's education and member of the New England Woman's Club, the first woman's club in the US, in 1882. In it, Darwin showed himself convinced that women were 'inferior intellectually' to men and that 'there seems $[\ldots]$ to be a great difficulty from the laws of inheritance, $[\ldots]$ in their becoming the intellectual equals of man'. In the same letter, he argued that women could be educated but 'that the early education of our children, not to mention the happiness of our homes, would $[. .$.$] greatly suffer'. { }^{136}$ Readers learned that Darwin saw 'greater intellectual vigour and power of invention in man' as 'the most able men will have succeeded best in defending and providing for themselves, their wives and offspring' ${ }^{137}$ In contrast, Darwin maintained, with their maternal instincts, 'greater tenderness and less selfishness', women differentiated themselves from men. ${ }^{138}$

Many men scientists such as Francis Galton, Darwin's cousin and British anthropologist known for his studies in eugenics, and the Swiss botanist Alphonse de Candolle expressed their misogynist sentiments and used Darwin passages as confirmations. ${ }^{139}$ The theory of natural selection and its assumptions of biologically conditioned gender differences in capacity and disposition could thus replace the theological justification for patriarchy derived from biblical stories such as that of the mythical Eve. The rib story in Genesis 2:20-22 and God's thundering to Eve ('I will greatly multiply thy sorrow and thy conception; in sorrow thou shalt bring forth children; and thy desire shall be thy husband, and he shall rule over thee' (Genesis 3: 16)) had always been preferred by misogynist and conservative men to the first chapter of Genesis, the simultaneous creation of men and women (Genesis 1: 27) which was often quoted by feminists in their counter-arguments. ${ }^{140}$ Thus, while the explanation for their inferiority shifted, women continued to be subjugated and deemed less worthy individuals than men.

Yet, women realised that the theory's focus on females' position in nature, for the first time in biological theorising, offered them a unique opportunity to discuss women's position in society. One of them was Barber who in 1868 discussed the impact sexual selection had on society with Trimen, who was of the opinion 'that Darwin has found out that the whole sexual system in nature requires setting to rights! ${ }^{141}$ She welcomed Trimen's attitude that-according to what is known about his opinion on his women colleagues and how he supported Barber-cannot be taken as sarcastic. He may have rather meant that Darwin brought clarity to how the sexual system in nature works rather than changing gender relations, 
as Barber wanted to understand his statement. While it is not clear how Barber came to embrace sexual selection in her observations on birds, it seems highly likely that she realised the theory's potential for advocating for women's rights and gender equality.

Barber's desire to strengthen women's position in society emerged in the 1860s. The Cape Colony's 1853 constitution had made the colony one of the most egalitarian in the British Empire. It gave any 'male person' over the age of twenty-one, regardless of race but with property worth twenty-five pounds, the right to vote and be elected as members of the House of Assembly. ${ }^{142}$ Women had no right to vote or hold a political position. As in The Great Reform Act (1832) in Britain, women were explicitly excluded by substituting the general word 'man' with 'male person', which happened for the first time in British and South African history. The Great Reform Act had allowed men who owned or rented property with an annual worth of ten pounds or more to vote. About half of the middle class could subsequently vote, which in total represented about $20 \%$ of all men in the country. The Second Reform Act (1867) later gave workingmen the vote, but not women. ${ }^{143}$ Andrew Bank has shown how racial attitudes at the Cape hardened after constitutional emancipation in 1853, which in turn resulted in the fostering of a broad colonial identity based on white alliance. ${ }^{144}$ Kirsten McKenzie's research has elucidated how the constitution disempowered women, as ideas of British domesticity were transferred to the Cape and a new gender order was introduced at the same time that set out distinctive roles for middle-class men and women in the political and domestic spheres, respectively. ${ }^{145}$ Women in America were to find themselves in a similar situation after the Fourteenth (1866) and Fifteenth Amendments (1870), which granted emancipated men slaves the right to vote but did not do the same for women in general, many of whom subsequently sought to extract from evolutionary theory that which would serve their feminist cause. ${ }^{146}$

Barber could not engage in politics and must have felt constrained in the 1860s, when she was also confronted with the presence of her husband and brothers for the longest continuous period of her adult life, in contrast to before when they had spent much time away from home, actively engaged in, among other endeavours, politics, agricultural matters and the Cape-Xhosa Wars. Through such experiences, Barber's perception of suffering under contemporary gender norms increased, which in turn encouraged her to turn to a theory which included elements that she could use to strengthen the position of women in society. 
In contrast, proponents of natural selection became fierce opponents of female self-determination among humans. Darwin noted differences between female and male 'secondary sexual characters' that consisted of males' 'organs of locomotion or prehension' and females' 'organs of nourishment or protection for the young'. ${ }^{147}$ This suggests that Darwin saw females as different due to their reproductive capacity that forced them to be 'passive materialists' to ensure their survival. ${ }^{148}$ With his concept of sexual selection, he stressed the difference between the sexes, but did not place females lower than males. Darwin's colleagues, such as the ornithologist John Gould, as will be seen in Chap. 8, or Alfred Russel Wallace, who simultaneously developed a theory similar to Darwin's natural selection, were more conservative with regard to females' position in nature and women's in society. ${ }^{149}$ Darwin argued that males evolved adaptive weapons for attack and self-defence in male-on-male intra-species combat, while females developed an aesthetic sense for choosing a male. ${ }^{150}$

Wallace explained the adaptive principle in males with natural selection, opposed the idea of female choice and became the most outspoken opponent of the latter. He proposed what English Darwinian philosopher Helena Cronin calls the " "good sense" female choice' view that 'females choose their mates for vigor or health, for territory size or nest quality the sort of sensible characteristics that natural selection would be choosing anyway'. ${ }^{151}$ In 1877, Wallace published his article 'On the Colours of Animals and Plants' in Macmillan's Magazine, ${ }^{152}$ rejecting without reservation the possibility of Darwinian female choice, which he deemed both unnecessary and an anthropomorphic notion. This attitude was partly a result of his spiritualist convictions, but also derived from his conception of natural selection as a sufficient explanation for evolution. ${ }^{153}$ Wallace had a profound impact among most Darwinians who avoided the subject of sexual selection and readily adopted his view that sexual selection was an ambiguous and superfluous hypothesis. ${ }^{154}$

The correspondence between Barber and Trimen which took place prior to the publication of her subsequent critique of Wallace suggests that she was harshly critical of the latter's position of women. She advocated both for being recognised as a woman scientist and against men's underestimation of women more generally. At the beginning of November 1877, she asked with heavy irony:

Did you see a long article in Macmillans Magazine by A. R. Wallace, in which he mentioned the changes in colour which take place in the pupa of 
Papilio nireus which I sent a description of to Mr Darwin? Then he goes on to say "these remarkable changes would perhaps not have been credited, had it not been for the previous observations of Mr Wood." This is rather flattering to one is it not! 155

By the end of the month, she still did

not think Wallace made a successful stand against Darwin's theory of sexual selection and in a great measure but not entirely I am bringing forward proofs of sexual selection having a great deal to do with the production of fine feathers, however, the causes of coloration in nature, are so wonderful, and multitudinous in their cases, that one could fill a volume on the subject, and spend a life time in their study, and then not know or describe the half of them. ${ }^{156}$

By overlooking her achievements ${ }^{157}$ as well as giving false credit to a $\mathrm{Mr}$ Wood, most likely English zoological illustrator T. W. Wood who had illustrated Wallace's The Malay Archipelago (1869) and Darwin's The Descent, Barber saw Wallace as a gatekeeper, who did not acknowledge her work properly due to her gender. Barber's charge was heightened by her sensitivity towards and constant fight against the misrecognition of her work, as discussed in Chap. 4 with regard to the article falsely published under 'Mr Layland'.

Barber therefore took issue with Wallace's chauvinistic attitude and attacked him in a response paper to his article in 1878, which was difficult to publish. For a decade, she had collected information and observations to accumulate evidence for selection by females in local butterflies, moths, spiders and birds, finding evidence in the process that colour in nature was never accidental. ${ }^{158}$

Like Darwin, she used many examples of birds to defend her position on sexual selection. She argued that male red-breasted sunbirds (Nectarinia afra), Cape canaries (Crithagra canicollis) and yellow finches (Hypanthornis olivaceus) displayed their beauty in 'love meetings', while females were attracted to the most aesthetically beautiful mate. This, she observed, was in contrast to female domestic fowls, which chose the strongest male. ${ }^{159}$ Besides these instances, Barber analysed the functions of colours among various species and described indicative or banner colour in polygamous birds that allowed them to keep together or to separate and later find each other. ${ }^{160}$ Protective colour is the colour that allows species such as the green wood-pigeon (Treron delalandii) in the Transkeian country to 
closely resemble their favourite fruit trees, the wild fig's foliage that is consequently 'the home of these birds' for offering them protection. ${ }^{161}$ Similarly, the young ostriches imitate 'the small black ant-heaps, which are by no means uncommon in the grassy localities, or on the plains where these birds have their nests', as do pupae with the plants they feed on. ${ }^{162}$

Deceptive colour, according to Barber, differed from mimicry in that it is neither protective nor permanent, but changeable and uncertain and 'purely for the purpose of misdealing and deceiving'. ${ }^{163}$ Examples she gave were the small grey mottled chameleon, the green chameleon of Griqualand West, the 'flower frog' (Hyperolius) and the gaily painted 'China spider'. Mimicry was for self-preservation as the ocelli in butterflies that represented eyes and in the case of different species of Satyridae made the toad see the eyes of a snake, 'its deadliest foe' and leave the butterflies in peace. ${ }^{164}$

In conclusion, Barber summarised that she had aimed to demonstrate 'to a certain extent the truth of Mr Darwin's Theory of "Female Selection", and to illustrate "the peculiarities to which colour in its manifold services is applied in nature, and the all-important influence which it has on the lives and habits of various creatures'.165

Barber had initially wanted to publish this article 'On the peculiar Colours of Animals in Relation to Habits of Life' abroad out of fear that only a few readers of the Transactions of the newly established South African Philosophical Society had read Wallace's paper. Furthermore, she aimed for a large transnational readership, thus sending the article to England. Presumably, she posted it to the Macmillan's Magazine or to Hooker, who she hoped would publish it for her. She wrote to Hooker in November 1878, pointing out to him that:

Some months ago I sent you a paper on colour and the effect it had on the habits of various creatures, and as I have not received a line from any of my Kew friends for so long, and the said paper has never been acknowledged I have come to the conclusion that probably it never reached you at all frequently they are lost that are sent to this out of the way part of the world our postal arrangements are not of the best kind the last "Kew Garden Report" never reached Kimberley $[\ldots]$ Be so kind as to send me a line to say whether the paper on "colour" ever reached you? 166

This passage indicates how important the paper was to her, as she hoped to prove a point: in terms of her observations of sexual selection, the status she attributed to females in nature and to voice her opinion on Wallace's unacceptable line of argumentation. Among the letters that have been 
archived at Kew Library, Art and Archives, there is no earlier letter from Barber in which she indicates having sent the paper. Therefore, it can be assumed that the letter was lost or that Hooker forwarded it to a publisher or journal without leaving a trace in Darwin's collection at Cambridge, the Linnean Society archives in London or the Royal Entomological Society in St Albans. What is certain is that Barber's article was not published in England. Four months after withholding the paper from Trimen, co-founder of the South African Philosophical Society and an editor of its Transactions, she sent it to him in November 1877 . He duly published the article in the journal's first issue and also made her the first woman corresponding member of the society. ${ }^{167}$ The published article did make its way into Darwin's archives in Cambridge, but the circumstances of how it got there remain unclear. ${ }^{168}$ Wallace, presumably reading Barber's paper and other literature on the topic, changed his mind and embraced female selection by the 1890s. ${ }^{169}$

Besides a few exceptions, however, the theory of sexual selection remained neglected until the second half of the twentieth century. ${ }^{170} \mathrm{It}$ was to take half a century until R. A. Fisher could explain why female birds chose male birds with characteristics that were 'downright deleterious', such as the peacock's tail. ${ }^{171}$ This long neglect by scientists also explains why the theory's significance for the feminist cause has only recently attracted more scholarly attention. In these recent studies, the focus was mainly on women who openly criticised Darwin's arguments as masculinist, such as the first ordained woman protestant minister in the US, Antoinette Brown Blackwell, or developed his concepts into gender theories, such as Clémence Royer in France. Blackwell's The Sexes Throughout Nature (1875) was the first feminist critique of evolutionary theory by a woman. She showed how gender-biased Darwin and Spencer had been and promoted more objective methods, such as 'a deeper reading of facts'. She challenged mainstream science to study women, to transgress boundaries of masculinity in scientific practice and argued for a 'Science of Feminine Humanity' that could be 'the ultimate arbiter of questions regarding sex difference' if it was accepted that 'the experience of women [ should] count for more [...] than the observation of the wisest men'. She thereby replaced patriarchal with matriarchal lines of reasoning. ${ }^{172}$ Royer (1830-1902) was a self-taught French scholar and lecturer on economics, philosophy and science, who translated Darwin's Origin of Species into French in 1862, deducted from it an evolutionary gender theory consisting of three phases. In the first, prehistoric men 
and women barely differed physically or mentally from each other. The scarcity of natural resources raised competitive pressures and a gendered division of labour thus developed in the second phase, in which females became caretakers while males hunted and sought subsistence for their families. In the third phase, in industrial society, gender asymmetries were no longer necessary even becoming counterproductive. Humans needed both traditionally female and male characteristics. Biological gender asymmetries were thus not present at first, but became necessary in order to reach the stage of civilisation in which they could now disappear. ${ }^{173}$

In 1913, the American author and journalist Floyd Dell had already recognised that the women's rights movement was 'a product of evolutionary science of the nineteenth century'. There had been 'women's rebellions' before, but 'modern science' gave humans 'a new view of the body, its functions, its needs, its claims upon the world' which provided 'the basis for a successful feminist movement'. ${ }^{174}$

Barber believed that the oppression of women was rooted in power relations rather than their biology, as will be detailed in Chap. 8. Inequalities which existed due to a lack of educational opportunities for women ${ }^{175}$ made her spot sexual selection's emancipatory potential. Barber's approach was to present proofs for gender equality in the otherthan-human animal world and urge humans who felt superior to act according to superior principles. She was a pragmatist who strongly believed in the Lamarckian notion of trying and Emersonian self-reliance with an underlying assumption that unhappiness is invariably selfinflicted. ${ }^{176}$ Yet, her individual will and self-reliance did not guarantee her self-actualisation and progress in the scientific world. Barber had to depend on men members of society who supported her to evolve and progress. She struggled to be heard and published and fought for the recognition of the importance of the theory of sexual selection as a means of advocating for women's rights. With the new generation of settlers at the Cape and industrialisation, women more and more felt the need for more rights and co-determination.

While Barber had previously hoped that she could make metropolitan scientists rely on her services as an illustrator, she now found a far more important niche for herself, becoming one of the first naturalists to research insect mimicry and camouflage and their role in the pollination of plants. While Trimen was more of an armchair entomologist who emphasised the 
importance of having access to large collections as well as the literature that she could not approach herself, Barber could observe butterflies in nature and experiment with them by rearing them in her laboratory-like garden. Barber and Trimen thus complemented one another, yet the different nature of their individual roles also illustrates the gendered division of labour at the time. Whereas women became increasingly accepted and

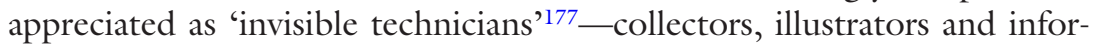
mants - theory remained a predominantly male preserve. Yet, Chap. 6 shows that Barber did not just circulate and provide corroborative evidence for Northern theories.

\section{Notes}

1. (Cohen 2011, 21).

2. St George's church was built from 1824 to 1830 and in 1853 with the appointment of a bishop became a cathedral. It was then agreed to add to the building and over the following decades a tower, spire, chancel and so on in popular neo-Gothic style. It is today known as The Cathedral of St Michael and St George. See (Gould 2011).

3. Letter to Harvey in Flora Capensis, quoted in (Mitford-Barberton 1934, $85)$.

4. See for example (Hunt 2005).

5. (Cohen 2011, 24).

6. (Turner 1983, 291).

7. (C. Darwin and Wallace 1858).

8. (C. Darwin 1859,61 ).

9. Darwin regretted not having called it 'Natural Preservation' instead. Darwin to Charles Lyell, Marine Parade/Eastbourne, 28 September 1860, Darwin Correspondence Project, Letter 2931.

10. RES, Trimen Correspondence, Box 17, Letter 31, Highlands, 24 August 1863.

11. (Fisher 1869); (Nelson 1992); (Parnell 2009).

12. (Ducker 1988, 326-327); https://www.tcd.ie/Botany/tercentenary/ 300-years/chairs/william-harvey.php, date accessed 22 March 2016. See (Webb 1966, 39). (William H. Harvey 1862); (Ducker 1972); (Huxley 1918, 1:516). Harvey's 'serio-comic squib': (William Henry Harvey 1860) in: Santry Book Repository, Trinity College Dublin, Pa 344/2. Also referred to as 'A Guess as to the Probable Origin of the Human Animal considered by the Light of Mr. Darwin's Theory of Natural Selection, and in Opposition to Lamarck's Notion of a Monkey Parentage' in R. Lloyd Praeger, "William Henry Harvey 1811-1866" in: (Oliver $1913,221)$. 
13. C.R. Darwin to J.D. Hooker, 30 May 1860, Darwin Correspondence Project, Letter 2818.

14. (Huxley 1918, 1:516).

15. Harvey to Gray, Trinity College Dublin, 3 November 1860, original at Gray Herbarium of Harvard University, reproduced in Ducker (ed.), The Contented Botanist, 330-332; mentioned in: Darwin to Asa Gray, Down, Bromley, Kent [Eastbourne], 26 September 1860, Darwin Correspondence Project, Letter 2930.

16. (Bowler 2009, 416).

17. (William H. Harvey 1861).

18. (F. Darwin 2007, 2:474).

19. Harvey to Darwin, Trinity College, Dublin, 19 May 1864, Darwin Correspondence Project, Letter 4503; Harvey to Darwin, 4. Winton Road/Leeson Park, Dublin, 8 November 1864, Darwin Correspondence Project, Letter 4665; Harvey to Darwin, 4. Winton Road/Leeson Park, Dublin, 10 November 1864, Darwin Correspondence Project, Letter 4668.

20. KLAA, Director's Correspondence Vol. 189, Letter 113, Barber to J. D. Hooker, Highlands, 26 December 1866. Elsewhere, Barber wrote: 'Oh Lord how wonderous are thy works, in wisdom "hast thou made them all".' Mary E. Barber, "The Wood Spiders (Notes from a Journal)", Tharfield, Kleinemond River, Cape Monthly Magazine 1870. The Prayer Book of 1662, 104:18, actually states: "O Lord, how manifold are thy works, in wisdom hast thou made them all" in (Cohen 2011, 65).

21. Barber to Hooker, KLAA, Directors' Correspondence, Vol. 189 Letter 114, Highlands, 9 May 1867.

22. (Layard 1867, 266-267).

23. Barber, Wanderings, Vol. 2, MS 10560 (b), 66, 69.

24. Barber, Wanderings, Vol. 1, MS 10560 (a), 38; Vol. 3, MS 10560 (c), $120-121$.

25. See for example RES, Trimen Correspondence, Box 18, Letter 88, Oatlands, 10 and 25 March 1873.

26. (Cohen 2011, 55, 58).

27. (de Beer 1983, 54); (Hunt 2005, 25).

28. (Endersby 2007, 3).

29. (Endersby 2007, 3).

30. (Endersby 2007, 3).

31. (Frederick 1885, 107; Polkinghorne 2005, 39).

32. (Kingsley 1880, 313-336).

33. (Endersby 2007, 3).

34. Biologist Steve D. Johnson has argued that 'amateur naturalists' such as Barber 'did not leave any institutional legacy of evolutionary biology in South Africa’ (Johnson 2009, 404). 
35. Address by Roderick Noble to the members of the Public Library, 23 May 1868, in (Dubow 2006a, 97).

36. See (Dubow 2004, 107-133; Dubow 2006b, 96-105; Livingstone 2013). For a revised version of Livingstone's paper presented in Basel, see (Livingstone 2016).

37. (Livingstone 2013, 14).

38. (Dubow 2004, 109).

39. (Dubow 2006a, 118-119).

40. (Barkly 1871, 13, 12, 11). Several extracts from the address are quoted in: (Editor 1871, 383).

41. http://www.victorianweb.org/science/science_texts/belfast.html, date accessed 16 October 2016.

42. KLAA, Director's Correspondence, Vol. 189, Letter 127, Barber to J. D. Hooker, Kimberley, 18 October 1874.

43. See for example (Weber 2000, 357-385).

44. Ralph Waldo Emerson's "Self-Reliance" in (The Riverside Library 1883, 45-87); originally published in (Emerson 1841). Also see, for example, (Blau 1977).

45. RES, Trimen Correspondence, Box 17, Letter 36.1, Highlands, 22 March 1864.

46. Barber, Wanderings, Vol. 3, MS 10560 (c), 101.

47. See for example (Robertson 1887, 33). Robertson claims that Henry Wadsworth Longfellow had been influenced by British poet William Wordsworth through American poet and newspaper editor William Cullen Bryant's nature studies.

48. Barber, Wanderings, Vol. 3, MS 10560 (c), 120.

49. KLAA, Misc. Reports Cape Colony etc. 1845-1915, Vol. 303, Letter 204, Barber to Hooker, Kimberley, 14 December 1877; Letter 208, Kimberley, 5 March 1878.

50. Barber, Wanderings, Vol. 3, MS 10560 (c), 99-100.

51. (Worster 2008, 370, 429, 438, quote: 448, from a letter to Howard Palmer, Secretary American Alpine Club, Martinez, California, 12 December 1912).

52. (Adams and Mulligan 2003, 34).

53. (Knechtel 2010, 261).

54. Thorough research in the Schreiner archive at the NELM (National English Literary Museum) in Grahamstown did not reveal any connection between the two. I thank registrar/archivist Cecilia Blight for her help.

55. Letter to Arthur Symons in (Cronwright-Schreiner 1924, 187-188); Letter to Havelock Ellis, Buxton, 5 August 1884, Harry Ransom Center, University of Texas, Austin: HRC/CAT/OS/2a-iv. 
56. (Schreiner 1926, 181).

57. RES, Trimen Correspondence, Box 17, Letter 35, Highlands, 10 February 1864.

58. (Barber 1871).

59. (Barber 1869).

60. KLAA, Director's Correspondence, Vol. 189, Letter 114, Barber to J. D. Hooker, Highlands, 9 May 1867.

61. (Cohen 2002, 207).

62. (C. Darwin 1862); The first letter from Darwin to Trimen was: Down, Bromley, Kent, 31 January 1863, Darwin Correspondence Project, Letter 3956. In it, Darwin thanks Trimen for his previous letter, a manuscript of his observations on South African orchids, and sketches which have not been found.

63. (Trimen 1864).

64. RES, Trimen Correspondence, Box 17, Letter 29, Highlands, 19 May 1863. Also see Chap. 2.

65. Trimen to Darwin, Colonial Office, Cape Town, Cape of Good Hope, 16, 17, and 19 July 1863, Darwin Correspondence Project, Letter 4243.

66. RES, Trimen Correspondence, Box 17, Letter 31, Highlands, 24 August 1863; Darwin to Gardeners' Chronicle, 4-5 June 1860, Darwin Correspondence Project, Letter 2826. The letter was published in the Gardeners' Chronicle and Agricultural Gazette, 9 June 1860, 528, as well as in the Entomologist's Weekly Intelligencer, 23 June 1860, 93-94, and 30 June 1860, 102-103 (see letter to H. T. Stainton, 11 June [1860]).

67. (Bates 1862); (Cohen 2002, 208-209).

68. RES, Trimen Correspondence, Box 17, Letter 61/1, Highlands, 1 August 1868; Letter 62/1, Highlands, 2 November 1868.

69. It was mentioned in: Proceedings of the Linnean Society of London, 81:3 (1869), xlii.

70. RES, Trimen Correspondence, Box 17, Letter 58/1, Highlands, 4 May 1867; Letter 60, 21 June 1868; Letter 68/2, 10 September 1869; Box 18, Letter 87, Colesberg Kop. New Rush, 22 May 1872; Letter 123, Grahamstown, 24 April 1885. See (Hooker 1855, 1:31).

71. Darwin to J. D. Hooker, Down, 25 December 1868, Darwin Correspondence Project, Letter 6512.

72. J. D. Hooker to Darwin, 23 December 1868, Letter 6511.

73. King James Bible, Cambridge Edition, Digital Electronic Text.

74. 'But, when our John hath quaff'd his ale, As little as the wind that blows, And warms itself against his nose, Kens he, or cares, which way he goes.' lst Canto XXIV. In her scientific correspondence, Barber frequently cited English poet and classical scholar Thomas Gray (1716-1771) and Scottish historian Thomas Carlyle (1795-1881). Barber often quoted verse 14 
from Gray's Elegy written in a Country Churchyard, 'Full many a flower is born to blush unseen,/And waste its sweetness on the desert air' in reference to her unwillingness to waste her knowledge and to remain "unseen"'. Carlyle: RES, Trimen Correspondence, Box 17, Letter 50, Highlands, 26 August 1866; Box 18, Letter 114, Grahamstown, 30 March 1882; Gray, Kew, Director's Correspondence, Vol. 189, Letter 111, Barber to Hooker, Highlands, 2 August 1866, may "waste their sweetness on the desert air" after verse 14 of the Elegy written in a Country Churchyard by Thomas Gray 'Full many a flower is born to blush unseen, And waste its sweetness on the desert air'. Carlyle was a racist thinker and reinforced her Social Darwinism, as his contemporary political polemics and the intersection of nationalism and imperialism in his work indicate. Curtain has demonstrated how the ideas of Carlyle lie at the heart of the hardening racism in metropolitan Britain. Andrew Bank has shown how Barber's oldest brother, John Mitford Bowker, borrowed phrases from Carlyle and fused them with an older theological racism in his speeches to Albany settlers. This aspect will be discussed in Chap. 7. See (Curtin 1965, especially chapter 15 "The Racists and their Opponents," 363-387); (Bank 1995, 28, 232).

75. See for example (Endersby 2009).

76. See for example: RES, Trimen Correspondence, Box 17, Letter 58/1, Highlands, 4 May 1867.

77. RES, Trimen Correspondence, Box 17, Letter 69, Highlands, 20 November 1869. There are neither records of correspondence nor specimens at the Hope Entomological Collections, Life Collections, Oxford University Museum of Natural History.

78. RES, Trimen Correspondence, Box 17, Letter 29, Highlands, 19 May 1863, to Letter 56, Highlands, 26 December 1866.

79. RES, Trimen Correspondence, Box 17, Letter 35, Highlands, 10 February 1864.

80. RES, Trimen Correspondence, Box 17, Letter 46, Highlands, 15 June 1866.

81. (Bates 1862).

82. (Alfred Russel Wallace 1865).

83. RES, Trimen Correspondence, Box 17, Letter 53.1, Highlands, I October 1866.

84. Trimen's searches in British collections are detailed in (Poulton 1924).

85. (Trimen 1869).

86. The butterflies known to Trimen as D. echeria and D. niavius are now classified as Amauris echeria and A. niavius, while the spelling of Danais has been changed to Danaus.

87. (Hewitson 1876, pt 72 (Oct. 1869)); (Cohen 2002, 212, 214). 
88. (Cohen 2002, 212).

89. (Bethune-Baker 1916, 231).

90. RES, Trimen Correspondence, Box 17, Letter 60.1, Highlands, 21 June 1868.

91. RES, Trimen Correspondence, Box 17, Letter 61, Highlands, 1 August 1868.

92. RES, Trimen Correspondence, Box 17, Letter 64 and 65, Highlands, 29 February [someone complemented 1869].

93. RES, Trimen Correspondence, Box 18, Letter 82, Highlands, 30 January 1871 .

94. See for example (Shanafelt 2003, 817, 821, 826-27, 829-831, 834-836, $839)$.

95. (Weale 1874).

96. (Trimen 1874).

97. (Trimen 1881).

98. RES, Trimen Correspondence, Box 18, Letter 89, New Rush, 4 December 1872.

99. RES, Trimen Correspondence, Letter 94, Kimberly, 21 July 1874; Letter 95, Kimberley, 19 November 1874.

100. KLAA, Director's Correspondence, Vol. 189, Letter 126, Barber to Hooker, Kimberley Diamond Fields Griqualand West, 30 June 1874.

101. Hooker to Darwin, Royal Gardens Kew, 29 August 1874, Darwin Correspondence Project, Letter 9610.

102. (Barber 1874, 520).

103. Illustrations in letters to Roland Trimen combined into one plate on the transformations of Papilio nireus in (Barber 1874, Plate IX).

104. (Barber 1874).

105. See discussion in Chap. 4, Figs. 4.1 and 4.2.

106. Darwin to Hooker, Down, Beckenham, Kent, 30 August 1874, Darwin Correspondence Project, Letter 9613; KLAA, Director's Letters, Vol. 189, Letter 126, Barber to Hooker, Kimberley, 30 June 1874; J. D. Hooker to Darwin, Royal Gardens Kew, 29 August 1874, Darwin Correspondence Project, Letter 9610.

107. See H. W. Bates to Darwin, Royal Geographical Society, l October 1874, Darwin Correspondence Project, Letter 9666.

108. See Transactions of the Entomological Society, Part 4 (Dec. 1874), xxiv.

109. Hooker to Darwin, Kew, 17 March 1875, Darwin Correspondence Project, Letter 9891.

110. (Bethune-Baker 1916, 231).

111. KLAA, Director's Correspondence, Vol. 189, Letter 104, Barber to J. D. Hooker, Highlands, 9 March (undated, filed as 1867, more likely 1868 or even 1869). 
112. (Ghiselin 1969, 220).

113. (C. Darwin 1859, 88); (Hamlin 2014, 8-9, 181).

114. (C. Darwin 1859, 89).

115. Including (Eliot 1859; Eliot 1860). Elizabeth Gaskell was one of Darwin's favourite writers. Jim Endersby finds it highly likely that he read all her novels including her last: (Gaskell 1866). See (Endersby 2009, 312); (Gerstel 2002, 43).

116. (Yeazell 1989, 42, 36).

117. (C. Darwin 1871b, 1:256).

118. (C. Darwin 1871b, 2:398).

119. (Montgomerie 2009, 477).

120. (C. Darwin 1871b, 2:38-238 (on birds), 316-384 (on humans)).

121. (Smith 2006, 85-86).

122. (C. Darwin 1871b, 2:36-37).

123. RES, Trimen Correspondence, Box 17, Letter 59 Highlands, 10 November 1867.

124. (Birkhead et al. 2014, 60).

125. (C. Darwin 1871a, 1:63).

126. (Exton 1871, 343). For more on Hugh Exton see: http://www.s2a3. org.za/bio/Biograph_final.php?serial=895, date accessed 30 May 2016.

127. (Exton 1871, 342).

128. Hooker to Darwin, 26 March 1871, Darwin Correspondence Project, Letter 7627.

129. See for example (Lilly 1894); (Vilbig 2011).

130. See (Livingstone 2013, 7).

131. 519. "Numida mitrata", in (Layard 1867, 266-267).

132. (Bowdler Sharpe 1875,220 ). No more sources are available to explain how Barber's views on sexual selection developed.

133. RES, Trimen Correspondence, Box 17, Letter 61, Highlands, 1 August 1868.

134. (Hamlin 2014, 3, 10-11).

135. (Erskine 1995, 100); also see, for example, (Alaya 1977); (Mosedale 1978); (Trecker 1974); (Hubbard et al. 1979; Hubbard et al. 1982; Lowe and Hubbard 1983); (Rosser and Hogsett 1984); (Russett 1989).

136. Darwin to Caroline A. Kennard (née Smith), 9 January 1882, Darwin Correspondence Project, Letter 13607.

137. (C. Darwin 1871b, 2:382-383).

138. (C. Darwin 1871b, 2:326).

139. See (Schär 2015, 78).

140. See (Hamlin 2014, "Chapter 1: Eve's Curse," 25-56).

141. (C. Darwin 1859, 88-89). Barber quotes Trimen's previous letter which has not survived. RES, Trimen Correspondence, Box 17, Letter 61, Highlands, 1 August 1868. 
142. (Crais 1992, 192).

143. (Christensen Nelson 2004, xxi-xxii).

144. (Bank 1995, 368, 371-372).

145. See (K. McKenzie 1996; K. E. McKenzie 1997, 6, 9, 10, 18, 33, 187, 201, 350).

146. See for example (Hamlin 2014, 46, 57, 61, 63).

147. (Young 1991, 95).

148. (Young 1991, 99).

149. (Young 1991, 96-97).

150. (Young 1991, 94).

151. (Cronin 1992, 287-288). See for example in: (Alfred R. Wallace 1877, 408). http://people.wku.edu/charles.smith/wallace/S272.htm last accessed 14 December 2018.

152. (Alfred R. Wallace 1877, 384-408), http://people.wku.edu/charles. smith/wallace/S272.htm last accessed 14 December 2018.

153. (Gayon 2010, 134).

154. (Gayon 2010, 136).

155. RES, Trimen Correspondence, Box 18, Letter 101, Kimberley, 2 November 1877.

156. RES, Trimen Correspondence, Box 18, Letter 102, Kimberley, 26 November 1877.

157. (Barber 1874).

158. RES, Trimen Correspondence, Box 18, Letter 102, Kimberley, 26 November 1877.

159. (Barber 1878, 29-31).

160. (Barber 1878, 31-33).

161. (Barber 1878, 34).

162. (Barber 1878, 36).

163. (Barber 1878, 37).

164. (Barber 1878, 44).

165. (Barber 1878, 45).

166. Barber to Hooker, KLAA, Director's Correspondence, Vol. 189, Letter 133, Kimberley, 19 November 1878.

167. RES, Trimen Correspondence, Box 18, Letter 102, Kimberley, 26 November 1877.

168. Barber presumably sent a copy of the published article to Darwin. All that is known is that there is a copy in Cambridge, the origins of which remain a mystery. Charles Darwin Pamphlet Collection G.1323 thanks to Adam J. Perkins, Curator of Scientific Manuscripts, Department of Manuscripts and University Archives Cambridge for our correspondence.

169. It has been argued that reading Edward Bellamy's Looking Backward (1888) convinced him of female choice. Bellamy in his novel created a socialist utopia about 'women's free, untrammelled power of sexual selec- 
tion'. Women were free, equal and chose partners based on attraction, which appealed to Wallace's political ideology. He argued: 'I hope I make it clear that women must be free to marry or not to marry before there can be true natural selection in the most important relationship of life.' 'In order to cleanse society of the unfit [and allow natural selection to proceed],' he explained, 'we must give to woman the power of selection in marriage, and the means by which this most important and desirable end can be attained will be brought about by giving her such training and education as shall render her economically independent.' (Alfred Russel Wallace 1894). For further discussion of Wallace's change of mind, see (Paul 1995, 37-39). Hinging on his acceptance of eugenic ideas, he argued that female choice improved social conditions and future offspring.

170. See (Gayon 2010, 136); (Mota 2009).

171. (Cronin 1992, 289).

172. (Hamlin 2014, 46, 57, 61, 63).

173. See (Schär 2015, 80-82). Royer's attitude towards gender equality resembles that of Barber's, as will be seen in Chap. 8 .

174. (Dell 1913, 44).

175. (Jaggar and Rothenberg 1984, 85).

176. RES, Trimen Correspondence, Box 17, Letter 36.1, Highlands, 22 March 1864.

177. See (Shapin 1989).

\section{REFERENCES}

Adams, William M., and Martin Mulligan, eds. 2003. Decolonizing Nature: Strategies for Conservation in a Post-colonial Era. London/Sterling: Earthscan Publications.

Alaya, Flavia. 1977. Victorian Science and the 'Genius' of Woman. Journal of the History of Ideas 38: 261-280.

Bank, Andrew. 1995. Liberals and Their Enemies: Racial Ideology at the Cape of Good Hope, 1820 to 1850. Cambridge: Cambridge University Press.

Barber, M.E. 1869. On the Structure and Fertilization of Liparis Bowkeri. Journal of the Linnean Society of London, Botany 10: 455-458. https://doi. org/10.1111/j.1095-8339.1869.tb02232.x.

- 1871. On the Fertilization and Dissemination of Duvernoia Adhatodoides. Journal of the Linnean Society of London, Botany 11: 469-472. https://doi. org/10.1111/j.1095-8339.1871.tb00156.x.

- 1874. Notes on the Peculiar Habits and Changes Which Take Place in the Larva and Pupa of Papilio Nireus. Transactions of the Royal Entomological Society of London 22: 519-521. 
1878. On the Peculiar Colours of Animals in Relation to Habits of Life. Transactions of the South African Philosophical Society 4: 27-45.

Barkly, Henry. 1871. Address Held on Saturday, 27th May 1871. In Proceedings at the Forty-Second Anniversary Meeting of the Subscribers to the South African Public Library, Cape of Good Hope, Cape Town.

Bates, Henry Walter. 1862. Contributions to an Insect Fauna of the Amazon Valley, Lepidoptera: Heliconidae. Transactions of the Linnean Society of London 23: 495-515.

de Beer, Gavin. 1983. Charles Robert Darwin [1876-1881] and Thomas Henry Huxley [1889], Autobiographies. Oxford: Oxford University Press.

Bethune-Baker, George T. 1916. Obituary, "Roland Trimen, F.R.S". The Entomologists' Record and Journal of Variation XXVIII: 231-236.

Birkhead, Tim, Jo Wimpenny, and Robert Montgomerie. 2014. Ten Thousand Birds: Ornithology Since Darwin. Princeton: Princeton University Press.

Blau, Joseph L. 1977. Emerson's Transcendentalist Individualism as a Social Philosophy. The Review of Metaphysics 31: 80-92.

Bowdler Sharpe, Robert. 1875. The Birds of South Africa, New ed., Thoroughly Revised and Augmented. London: Bernhard Quarith.

Bowler, Peter J. 2009. In Retrospect. Charles Darwin and His Dublin Critics: Samuel Haughton and William Henry Harvey. Proceedings of the Royal Irish Academy 109C: 409-420.

Christensen Nelson, Carolyn. 2004. Literature of the Women's Suffrage Campaign in England. Peterborough: Broadview Press.

Cohen, Alan. 2002. Roland Trimen and the Merope Harem. Notes and Records: The Royal Society Journal of the History of Science 56: 205-218.

- 2011. In a Quiet Way: The Life of Mary Elizabeth Barber, South Africa's First Lady Natural Historian 1818-1899.

Crais, Clifton C. 1992. White Supremacy and Black Resistance in Pre-Industrial South Africa: The Making of the Colonial Order in the Eastern Cape, 1770-1865. Cambridge: Cambridge University Press.

Cronin, Helena. 1992. Sexual Selection: Historical Perspectives. In Keywords in Evolutionary Biology, ed. Evelyn Fox Keller and Elisabeth A. Lloyd, 286-293. Cambridge: Harvard University Press.

Cronwright-Schreiner, Samuel C. 1924. The Life of Olive Schreiner. London: Fisher Unwin Ltd.

Curtin, Philip D. 1965. The Image of Africa: British Ideas and Action, 1780-1850. London/Madison: Macmillan/University of Wisconsin Press.

Darwin, Charles. 1859. The Origin of Species by Means of Natural Selection, or the Preservation of Favoured Races in the Struggle for Life. London: John Murray.

- 1862. On the Various Contrivances by Which British and Foreign Orchids Are Fertilised by Insects, and on the Good Effects of Intercrossing. London: John Murray. 
1871a. The Descent of Man, and Selection in Relation to Sex. Vol. 1. 2 vols. London: John Murray.

- 1871b. The Descent of Man and Selection in Relation to Sex. Vol. 2. 2 vols. New York: D. Appleton and Company.

Darwin, Francis, ed. 2007. The Life and Letters of Charles Darwin. Vol. 2. Teddington: Echo Library.

Darwin, Charles, and Alfred Wallace. 1858. On the Tendency of Species to Form Varieties; and on the Perpetuation of Varieties and Species by Natural Means of Selection. Journal of the Proceedings of the Linnean Society of London. Zoology 3 : 45-62. https://doi.org/10.1111/j.1096-3642.1858.tb02500.x.

Dell, Floyd. 1913. Women as World Builders: Studies in Modern Feminism. Chicago: Forbes and Company.

Dubow, Saul. 2004. Earth History, Natural History, and Prehistory at the Cape 1860-1875. Comparative Studies in Society and History 46: 107-133.

- 2006a. A Commonwealth of Knowledge: Science, Sensibility and White South Africa 1820-2000. Oxford: Oxford University Press.

- 2006b. Earth History and Evolutionism. In A Commonwealth of Knowledge: Science, Sensibility and White South Africa 1820-2000, ed. Saul Dubow. Oxford: Oxford University Press.

Ducker, Sophie C. 1972. Harvey, William Henry (1811-1866). In Australian Dictionary of Biography, ed. National Centre of Biography. Canberra: Australian National University.

- 1988. The Contented Botanist. Letters of W. H. Harvey About Australia and the Pacific. Melbourne: Melbourne University Press.

Editor. 1871. Notes by the Editor. Cape Monthly Magazine, 2.

Eliot, George. 1859. Adam Bede. 3 vols. London/Edinburgh: William Blackwood and Sons.

- 1860. The Mill on the Floss. In The Clarendon Edition of the Novels of George Eliot: The Mill on the Floss, George Eliot, ed. Gordon S. Haight. Oxford University Press. doi:https://doi.org/10.1093/oseo/instance.00191530.

Emerson, Ralph Waldo. 1841. Essays: First Series. Boston: J. Munroe and Company. Endersby, Jim. 2007. "Creative Designs?" (A Review of the Works of Charles Darwin). Times Literary Supplement (London, 16 March), 3.

- 2009. Sympathetic Science: Charles Darwin, Joseph Hooker, and the Passions of Victorian Naturalists. Victorian Studies 51: 299-320.

Erskine, Fiona. 1995. The Origin of Species and the Science of Female Inferiority. In Charles Darwin's the Origin of Species: New Interdisciplinary Essays, Texts in Culture Series, ed. David Amigoni and Jeff Wallace, 95-121. New York: Manchester University Press.

Exton, Hugh. 1871. The Philosophy of Bird's Nests in Relation to Instinct. Cape Monthly Magazine, 342-354. 
Fisher, Lydia Jane. 1869. Memoir of W. H. Harvey, M.D., F.R.S., etc. Late Professor of Botany, Trinity College, Dublin with Selections from His Journal and Correspondence. London: Bell and Daldy.

Frederick, Lord Bishop of Exeter. 1885. The Relations Between Religion and Science. Eight Lectures Preached Before the University of Oxford in the Year 1884. London: Macmillan and Co.

Gaskell, Elizabeth. 1866. Wives and Daughters: An Every-Day Story. 2 vols. London: Smith, Elder and Co.

Gayon, Jean. 2010. Sexual Selection: Another Darwinian Process. Comptes Rendus Biologies 333: 134-144.

Gerstel, Jennifer. 2002. Sexual Selection and Mate Choice in Darwin, Eliot, Gaskell, and Hardy. Graduate Department of English, University of Toronto.

Ghiselin, Michael T. 1969. The Triumph of the Darwinian Method. Berkeley: University of California Press.

Gould, Charles. 2011. Grahamstown Cathedral: A Guide and Short History, Eastern Cape Reprints, ed. Jeanette Eve. Grahamstown: Cory Library.

Hamlin, Kimberly A. 2014. From Eve to Evolution: Darwin, Science, and Women's Rights in Gilded Age America. Chicago/London: The University of Chicago Press.

Harvey, William H. 1860. An Inquiry into the Probable Origin of the Human Animal, on the Principles of Mr. Darwin's Theory of Natural Selection, and in Opposition to the Lamarckian Notion of a Monkey Parentage. Dublin: Privately Published.

- 1861. On 'Omne Vivum ex Ovo', or, the Natural Evolution of Organic Species Considered. Dublin Hospital Gazette.

- 1862. Charles and Josiah: or Friendly Conversations Between a Churchman and a Quaker. London/Dublin: Hodges, Smith and Co.

Hewitson, William Chapman. 1876. Illustrations of New Species of Exotic Butterflies, Selected Chiefly from the Collections of $W$. W. Saunders and W. C. Hewitson (1856-1876). London: John Van Voorst.

Hooker, Joseph Dalton. 1855. Himalayan Journals: Notes of a Naturalist in Bengal, the Sikkim and Nepal Himalayas, the Khasia Mountains, Ecc., New Edition, Carefully Revised and Condensed. Vol. 1. London: John Murray.

Hubbard, Ruth, Mary Sue Henifin, and Barbara Fried, eds. 1979. Women Look at Biology Looking at Women: A Collection of Feminist Critiques. Boston: G. K. Hall.

Feminist Essays and a Comprehensive Bibliography. Cambridge, MA: Schenkman Publishing Company.

Hunt, Stephen E. 2005. 'Free, Bold, Joyous': The Love of Seaweed in Margaret Gatty and Other Mid-Victorian Writers. Environment and History 11: 5-34.

Huxley, Leonard. 1918. Life and Letters of Sir Joseph Dalton Hooker. Vol. 1. London: John Murray. 
Jaggar, Alison, and Paula Rothenberg. 1984. Feminist Frameworks: Alternative Theoretical Accounts of the Relations Between Women and Men. 2nd ed. New York: McGraw-Hill Co.

Johnson, Steve D. 2009. Darwin's Legacy in South African Evolutionary Biology. Review Article, South African Journal of Science 105: 403-409.

Kingsley, Charles. 1880. The Natural Theology of the Future, Read at Sion College, 10 January 1871. In The Works of Charles Kingsley, Scientific Lectures and Essays, 19, 313-336. London: Macmillan.

Knechtel, Ruth. 2010. Olive Schreiner's Pagan Animism: An Underlying Unity. English Literature in Transition, 1880-1920 53: 259-282.

Layard, Edgar Leopold. 1867. The Birds of South Africa: A Descriptive Catalogue of All the Known Species Occurring South of the 28th Parallel of South Latitude. Cape Town/London: Juta/Longman, Green \& Co.

Lilly, William Samuel. 1894. Newman, John Henry. In Dictionary of National Biography, ed. Leslie Stephen, 40, Myllar to Nichols, 340-351. London: Smith, Elder, and Co.

Livingstone, David N. 2013. Debating Darwin at the Cape. Department of History, University of Basel.

- 2016. Debating Darwin at the Cape. Journal of Historical Geography 52: 1-15.

Lowe, Marian, and Ruth Hubbard, eds. 1983. Woman's Nature: Rationalizations of Inequality, The Athene Series. New York: Pergamon Press.

McKenzie, Kirsten E. 1996. Wollstonecraft's Models? Female Honour and Sexuality in Middle-Class Settler Cape Town, 1800-1854. Kronos 23: 57-74.

. 1997. Gender and Honour in Middle-Class Cape Town: The Making of Colonial Identities 1828-1850. PhD Thesis, University of Oxford, Oxford.

Mitford-Barberton, Ivan. 1934. The Barbers of the Peak. A History of the Barber, Atherstone, and Bowker Families. Oxford: Oxford University Press.

Montgomerie, Robert. 2009. Perspectives in Ornithology: Charles Darwin's Fancy. The Auk: An International Journal of Ornithology 126: 477-484.

Mosedale, Susan Sleeth. 1978. Science Corrupted: Victorian Biologists Consider 'The Woman Question'. Journal of the History of Biology 11: 1-55.

Mota, Paulo Gama. 2009. Darwin's Sexual Selection Theory - A Forgotten Idea. Anthropologia Portuguesa 26/27: 149-161.

Nelson, E. Charles. 1992. William Henry Harvey as Colonial Treasurer at the Cape of Good Hope: A Case of Depression and Bowdlerised History. Archives of Natural History 19: 171-180.

Oliver, F.W., ed. 1913. Makers of British Botany: A Collection of Biographies by Living Botanists. Cambridge: Cambridge University Press.

Parnell, John. 2009. W. H. Harvey. In Dictionary of Irish Biography: From the Earliest Times to the Year 2002, ed. James McGuire and James Quinn, vol. 4, 513-514. Cambridge: Cambridge University Press. 
Paul, Diane B. 1995. Controlling Human Heredity, 1865 to the Present. Atlantic Highlands: Humanities Press.

Polkinghorne, John. 2005. Exploring Reality: The Intertwining of Science and Religion. New Haven/London: Yale University Press.

Poulton, E.B. 1924. Papilio Dardanus. The Most Interesting Butterfly in the World. Journal of the East Africa Natural History Society 20: 4-22.

Robertson, Eric S. 1887. Life of Henry Wadsworth Longfellow. London: Walter Scott.

Rosser, Sue, and Charlotte Hogsett. 1984. Darwin and Sexism: Victorian Causes, Contemporary Effects. In Feminist Visions: Toward a Transformation of the Liberal Arts Curriculum, ed. Diane Fowlkes and Charlotte McClure, 42-52. Tuscaloosa: University of Alabama Press.

Russett, Cynthia Eagle. 1989. Sexual Science: The Victorian Construction of Womanhood. Cambridge: Harvard University Press.

Schär, Bernhard C. 2015. Evolution, Geschlecht und Rasse: Darwin's Origin of Species in Clémence Royers Übersetzung. In Die Naturforschenden: Auf der Suche nach Wissen über die Schweiz und die Welt, 1800-2015, ed. Patrick Kupper and Bernhard C. Schär, 69-85. Baden: Hier und Jetzt.

Schreiner, Olive. 1926. From Man to Man. London: Fisher Unwin Ltd.

Shanafelt, Robert. 2003. How Charles Darwin Got Emotional Expression Out of South Africa (and the People Who Helped Him). Society for Comparative Study of Society and History 45: 815-842.

Shapin, Steven. 1989. The Invisible Technician. American Scientist 77: 554-563.

Smith, Jonathan. 2006. Picturing Sexual Selection: Gender and Evolution of Ornithological Illustration in Charles Darwin's Descent of Man. In Figuring It Out: Science, Gender, and Visual Culture, ed. Ann B. Shteir and Bernard V. Lightman, 85-109. Lebanon: Dartmouth College Press.

The Riverside Library. 1883. Essays by Ralph Waldo Emerson, First and Second Series. Boston/New York: Houghton Mifflin Company.

Trecker, Janice Law. 1974. Sex, Science and Education. American Quarterly 26: 352-366.

Trimen, Roland. 1864. On the Fertilisation of Disa Grandiflora by Roland Trimen of the Colonial Office Cape Town: Drawn Up from Notes and Drawings Sent to C. Darwin. Journal of the Proceedings of the Linnean Society (Botany) 7: 144-147.

- 1869. On Some Remarkable Mimetic Analogies Among African Butterflies. Transactions of the Linnean Society of London 26: 497-522.

- 1874. Observations on the Case of Papilio Merope, Auct. with an Account of the Various Known Forms of That Butterfly. Transactions of the Entomological Society of London 22: 137-153.

- 1881. Note on the Capture of the Paired Sexes of Papilio cenea, Stoll. (P. Merope, Auct.), in Natal. Transactions of the Entomological Society of London 29: 169-170. 
Turner, Gerard L'Estrange. 1983. Nineteenth-Century Scientific Instruments. London/Berkeley, Los Angeles: Sotheby Publications/University of California Press.

Vilbig, Ryan. 2011. John Henry Newman's View of the 'Darwin Theory'. Newman Studies Journal 8: 52-61.

Wallace, Alfred Russel. 1865. On the Phenomena of Variation and Geographical Distribution as Illustrated by the Papilionidae of the Malayan Region (A Paper Read at the Linnaean Society of London Meeting of 17 March 1864) 25: 1-71.

- 1877. The Colours of Animals and Plants. Macmillan's Magazine.

- 1894. Women and Natural Selection. Lucifer the Light-Bearer, September 15 and October 4.

Weale, James Philip Mansel. 1874. Notes on the Habits of Papilio Merope, with a Description of Its Larva and Pupa. Transactions of the Entomological Society of London 22: 131-136.

Webb, David A. 1966. William Henry Harvey 1811-1866 and the Tradition of Systematic Botany. Hermathena 103: 32-45.

Weber, Alan S., ed. 2000. Nineteenth Century Science: An Anthology. Peterborough: Broadview Press.

Worster, Donald. 2008. A Passion for Nature: The Life of John Muir. Oxford: Oxford University Press.

Yeazell, Ruth Bernard. 1989. Nature's Courtship Plot in Darwin and Ellis. Yale Journal of Criticism 2: 33-53.

Young, Penny. 1991. The Politics of Love: Sexual Selection Theory and the Role of the Female. Nexus 9: 92-106.

Open Access This chapter is licensed under the terms of the Creative Commons Attribution 4.0 International License (http://creativecommons.org/licenses/ by $/ 4.0 /$ ), which permits use, sharing, adaptation, distribution and reproduction in any medium or format, as long as you give appropriate credit to the original author(s) and the source, provide a link to the Creative Commons licence and indicate if changes were made.

The images or other third party material in this chapter are included in the chapter's Creative Commons licence, unless indicated otherwise in a credit line to the material. If material is not included in the chapter's Creative Commons licence and your intended use is not permitted by statutory regulation or exceeds the permitted use, you will need to obtain permission directly from the copyright holder.

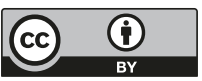

